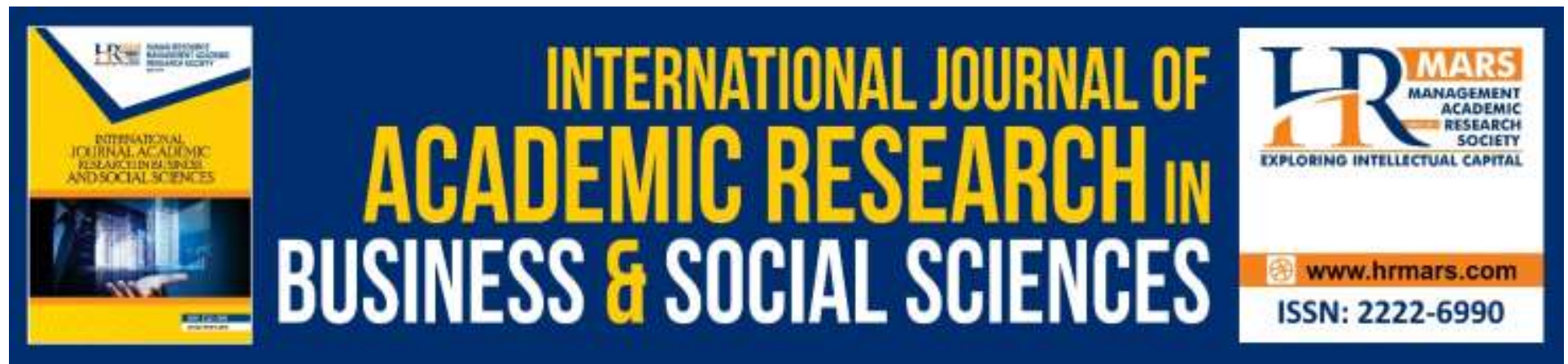

\title{
Student Team Achievement Division (STAD) Method: To Improve the Descriptive Writing Skills of Primary 5 Pupils
}

Marryta anak Udit, Harwati Hashim

To Link this Article: http://dx.doi.org/10.6007/IJARBSS/v10-i2/6954

DOI:10.6007/IJARBSS/v10-i2/6954

Received: 17 January 2020, Revised: 04 February 2020, Accepted: 12 February 2020

Published Online: 29 February 2020

In-Text Citation: (Udit \& Hashim, 2020)

To Cite this Article: Udit, M. A., \& Hashim, H. (2020). Student Team Achievement Division (STAD) Method: To improve the Descriptive Writing Skills of Primary 5 Pupils. International Journal of Academic Research in Business and Social Sciences, 10(2), 635-647.

Copyright: (C) 2020 The Author(s)

Published by Human Resource Management Academic Research Society (www.hrmars.com)

This article is published under the Creative Commons Attribution (CC BY 4.0) license. Anyone may reproduce, distribute, translate and create derivative works of this article (for both commercial and non-commercial purposes), subject to full attribution to the original publication and authors. The full terms of this license may be seen at: http://creativecommons.org/licences/by/4.0/legalcode

Vol. 10, No. 2, 2020, Pg. 635 - 647

Full Terms \& Conditions of access and use can be found at http://hrmars.com/index.php/pages/detail/publication-ethics 


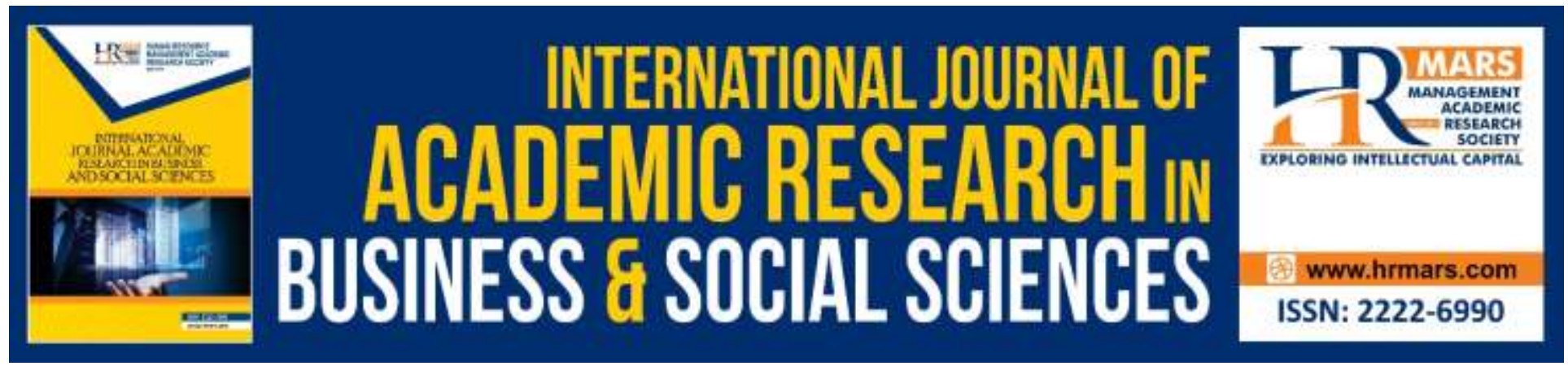

\title{
Student Team Achievement Division (STAD) Method: To Improve the Descriptive Writing Skills of Primary 5 Pupils
}

\author{
Marryta anak Udit ${ }^{1,2}$, Harwati Hashim ${ }^{2}$ \\ SK Batu Niah¹, Faculty of Education, Universiti Kebangsaan Malaysia (UKM), 43600 Bangi, \\ Selangor, Malaysia. ${ }^{2}$
}

\begin{abstract}
This article seeks to clarify the usage of Student Team Achievement Division (STAD) Method in improving the descriptive writing skills of Primary 5 pupils in a school in Sarawak. STAD Method is one of the simplest cooperative learning approaches. STAD Method encourages pupils to work collaboratively in order to enhance learning performance. The sample group for this study were thirty-four pupils of Primary 5. The data were collected by using pre and post-test, survey and groups' interview. This study will provide a direction for research in the future which may improve the pedagogy to learn writing in ESL classroom by using cooperative learning approach. Keywords: Writing Skills, ESL Students, STAD Method, Cooperative Learning Approach, Descriptive Writing Skills

\section{Introduction}

Education plays an essential role to build a developed country. Future generations have to be fully educated to make our country on par with other first class world countries. To achieve this mission, society should realized the importance of education. The quality of our education system should be improved. Teaching approaches can be applied by the teachers in classrooms. One of the approaches is cooperative learning approach. Education system in our country is more examoriented. This leads the pupils to focus on their study individually and do not interested in the cooperative learning approach. They tend to have competition among themselves on who get higher marks in the examination. Hence, this makes the cooperative learning approach to be neglected in the lesson.

In 21st Century teaching and learning classroom, teachers and pupils are complementing each other during the lessons. Instead of giving lessons by chalk and talk, teachers act as the facilitator during the task. Pupils become the active participants where they find information, discuss, and complete the tasks given by teachers. This approach requires the pupils to work collaboratively to achieve certain goals.
\end{abstract}


Cooperative learning approach gives opportunity for the pupils to work in a group. They can interact to discuss and exchange ideas which result in achieving the same objectives. In cooperative learning, no pupil is left behind. When pupils work in group, they can share their ideas and discuss among each other. They will not be afraid of making mistakes as it is a way for them to learn the subjects. The pupils can have higher level of self-esteem when working in group as they can support each other. This is supported by Jacobs (2006) where he mentioned that when pupils are having positive interdependence, they have the perception among group members that what helps one group member helps all, and what hurts one group member hurts all.

In this era of modernisation, English plays a significant role among the societies. In Malaysia, English is taught as a second language in all schools. Malaysia education system came out with many programmes to improve pupils' efficiency in using English. In the English language, there are four major skills which are listening, reading, speaking and writing. Writing is one of the important component in learning English. Based on a study by Rietdijket et al. (2018), the function of writing is to enable pupils in communication, function in society, acquire knowledge and to display what they have learned. Pupils have to be able to write clearly to convey the correct meaning to others.

Koster et al. (2015) studied that pupils are hardly progress in their writing competencies from grade 4 to grade 6 . This is supported by Nunan (1999) as he mentioned that writing has been one of the most difficult skill in learning the first and second language. As English is the second language for the Malaysian pupils, they show low mastery in writing and struggle very hard to write. This result was shown in the UPSR 2017 of English writing for national primary school decrease from $77.1 \%$ in the year of 2016 to $73.6 \%$ in the year of 2017. Besides, the 2005 School Certificate Examination Report on English Language 2 acknowledged that most of the candidates have yet to be proficient in writing skills in English at the required level in the 2005 School Certificate Exam Report (Samuel et al, 2008). This shows that the proficiency of Malaysian pupils in writing is still in a low level.

Malaysian pupils found it to be limited in terms of competency in writing skills (Chitravelu et. al, 2005). Pupils have the difficulties to expand their ideas in their writing. They have limited information about the tasks that they are going to write. This is the same situation happens in the school of this research conducted. They have limited competency in their writing skills. Thus, this paper aims to explore the use of STAD Method (Cooperative Learning Approach) to improve the descriptive writing skills of primary 5 pupils.

\section{Literature Review \\ Writing Skill}

Recent theorists of second language learning have the opinion that writing is important for second language learning. Writing give chances for the pupils to share their knowledge and ideas in order to learn better. McMillan \& Weyers (2007) reflects that, "Writing is a challenging and fulfilling activity. It brings about all your relevant knowledge and understanding of a topic in response to a particular task." These researchers pointed that it is challenging when it comes to writing. It is also a skill that require longer time for the pupils to master. At the same time, the pupils gain benefits when they learn writing where they can grasp the topic better in the process 
of writing the task. The process itself makes the pupils explore more about the topic that they are working on.

During the process of writing, the pupils can have deeper levels of reflection and thinking. According to Roybal (2012), the key component of good writing is the use of critical thinking skills. This researcher supports the current study of using STAD Method to teach writing as the method require the pupils to think actively during the writing activities. Hence, this means that good writing skill needs the pupils to organize and structure their ideas and information to achieve the requirements of the writing task given. Pupils have to work in their team where they find information and ideas, then they have group discussion on the information. In the process, they have to organize and structure their ideas so that all of the team members understand the ideas clearly. This requires the thinking skills of the pupils to be able to follow the correct process.

Donavan as quote by Ahmad (2015) emphasized that writing is a way for communication that develops ideas and information. Pupils write their thoughts on the writing not only for themselves, it is to be shared with others. Good writers should be able to express their ideas clearly to the readers for better understanding. Pupils have the chances to share their writing with others. Writing should be clear and accurate to ensure there is no any misunderstanding and misconception. The ideas and information in writing must be correct in order to deliver the correct messages. Hence, this enhances the current study about the importance of the process of writing skills among the pupils.

\section{Cooperative Learning Approach}

Writing is a vital skill that pupils should master by the end of their primary school. Teachers should work on teaching techniques to achieve the goal. One of the approaches that teachers can enforce in the classroom is through cooperative learning approach.

This approach is a way where the pupils work in group to enhance learning and improve their academic performances. As a group, the pupils get the opportunities to work and share understanding of the tasks. As stated by Wang (2007), the pupils can learn together on the process and development of learning as they interact among the high achievers and low achievers. Besides, their social skills are improved as they need to communicate and collaborate among themselves. The pupils will be more freely to discuss and argue in their group which allow them to apply higher order thinking skills.

Cooperative learning gives opportunities to the pupils to work within their group. Roger and Johnson (1994) stated this approach as a "process gain" and the knowledge transfer from group to individual. The pupils get the chances to work actively during the cooperative learning approach. The pupils can be active learners that work together with others in their writing. The pupils can be the one that teach their friends and in the mean time, they get the knowledge in return.

\section{The STAD Method and Academic Achievement}

The Student Team Achievement Division (STAD) Method is designed by Slavin (1994). It is one of the most popular among the cooperative learning method that teachers use in their classrooms. Previous studies indicated that STAD method is a student-centered approach where the pupils active participants in their learning. 
By using STAD method, pupils cooperate in groups of heterogenous members to achieve the similar goal (Ishtiaq et al., 2017). According to Slavin (1994), the STAD method is where the pupils are divided into groups of four or five members consist of mixed abilities, backgrounds and gender. The members are consisting of high, moderate and low achievers of any races or gender. This is to ensure that they work as a team and help each other to gain knowledge from the lessons. Those pupils who are high achievers can help to guide their low achievers team members in completing tasks given by teacher.

Slavin (1994) also concludes that STAD method is one of the simplest method in cooperating learning that consists of five components. These components are presentations, group work, quizzes, individual improvement scores and team recognition. Teacher can use these different components to apply STAD method in their teaching and learning process. These components allow the pupils to learn collaboratively in their team. Zarei and Keshavarz (2011) stated that the pupils work as a team in order to master the new lesson taught by the teacher. As for the accountability of every pupils, each of them will be tested individually and their scores are compared with their previous test scores. This is where the use of pre-test and post test are important. Hence, with this method applied, teachers will be able to assess pupils holistically according to their team work and individual performance in their writing.

\section{Student-Centered Approach}

The Student-centered learning $(\mathrm{SCL})$ approach aims at helping students to be active participants and share ideas in the learning process. Teachers act as the facilitators to ensure the pupils become independent learners. This approach makes the pupils to be responsible in acquiring knowledge. Leo Jones (2007) shared that "The student-centered approach helps students to develop a 'can-do' attitude. It is effective, motivating, and enjoyable." This indicates the SCL approach lets the pupils to discover and experiment the writing process with the teachers as the facilitators. They have to be independent to discover their ideas and develop the ideas into writing.

According to Cornelius, Jeffry and Adam (2010) a student-centered instruction is an approach that facilitate relationships, every learners' uniqueness and also learning processes to make pupils success through their engagement. This study focuses on the student-teacher relationship where the pupils are the doer while teachers are the facilitators. SCL approach also cater to every pupils' uniqueness without left anyone behind. Besides, SCL approach gives opportunities to pupils undergo the process of learning and teacher-student collaboration. As the activities in the classroom are student-centered, the pupils will have to come out with their own ideas and information to interpret the knowledge with the teachers as facilitators. Pupils are exposed to the process rather than being spoon-fed by others.

There are some characteristics of SCL approach that McCombs and Whistler (1997) had listed. Firstly, SCL classrooms facilitate learning by increasing the motivation and effort of the pupils. Secondly, the teachers has to learn that each learner is unique and have their own learning styles, abilities and talents. Thirdly, SCL is a constructive process that connected pupils' prior knowledge and experiences. Next, SCL requires individualization, interaction, and integration. It means that pupils have to create their own knowledge, interact with others about the knowledge and then to have the integration of the knowledge. Lastly, SCL changes the roles of pupils and 
the teachers where the pupils become the active learners. These characteristics clearly shows that SCL approach is where the pupils involve in the building of the knowledge in a meaningful and enjoyable ways.

$\mathrm{SCL}$ approach is used widely by teachers in English classroom. It is to allow the pupils get fully participate and express themselves in the classroom.

\section{Methodology}

\section{Participants}

The participants of this study were thirty four pupils of Primary 5. The pupils were pupils of mixed ability in their performances and proficiency level in English Language. They were chosen based on their performance level, gender, and achievement.

\section{Instruments}

This study used an action research. The quantitative and qualitative approaches are used in this study. The researcher use STAD Method in the class of Primary 5 pupils. Firstly, a pre-test (descriptive essay writing) was conducted with the pupils. This is to get the data to be compared to the post test later. After that, the action research was conducted for six weeks in the school with the same pupils. They were taught to write descriptive writing using STAD Method.

After the action research was completed, researcher gave a post test which is similar to the pre-test of the pupils. Then, a survey questionnaire consisted of three emerging themes about the use of STAD Method in classroom was conducted with these pupils. The quantitative data were obtained from the pre-test, the post test and survey questionnaire. This quantitative data was analyzed using descriptive statistics.

Meanwhile, the qualitative data was obtained from semi-structured interviews with the pupils. The qualitative data was analyzed based on three emerging themes. The researcher used English to ask interview questions and the participants answered using English and Bahasa Malaysia. The researcher transcribed and translated the interview data into English for this research.

Spiral steps in action research by Kemmis and McTaggart (1988) as shown in Figure 1 were used in this study. The steps are: Planning, Acting, Observing and Reflecting. 


\section{REFLECT}
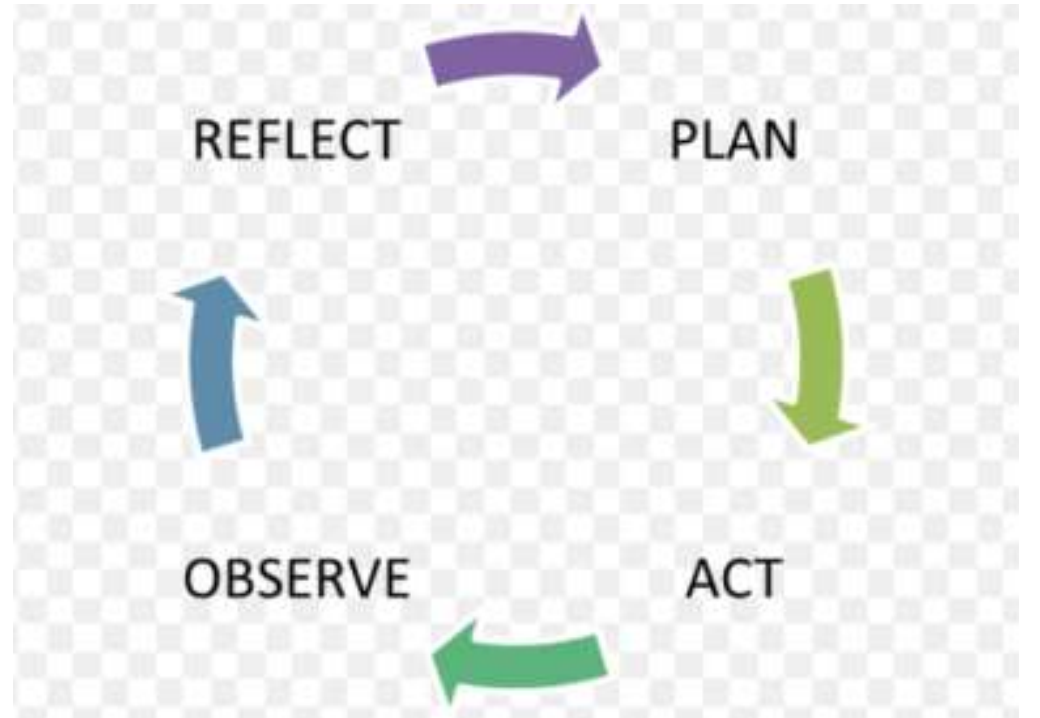

Figure 1 Spiral Steps in Action Research by Kemmis and McTaggart

During the planning process, the teacher analyzed the pupils' problems in their writing skills and planned strategic actions to help them. In this study, the teacher planned to implement the STAD method to enhance pupils' descriptive writing skills. In the acting stage, the teacher implemented the planned strategies (the STAD method) over a period of 6 weeks ( 1 hour per week, one essay in two weeks) in the ESL classroom. Teacher used in STAD method in class to teach descriptive writing by following all the steps.

During observation, the teacher documented the effects of the action by using appropriate measures. According to Kemmis and McTaggart (1988), the observation data may originate from various sources including the teacher's professional journal, test papers, checklists, interviews and others. In this study, the researcher obtained the data through a pre-test and a post-test, survey questionnaire and semi-structured interviews with the pupils. These instruments then lead the teacher to gain the result from the use of STAD method in teaching descriptive writing. In the final stage, the teacher reflected on the actions during the action research. In order to do the reflection, the teacher discussed with the pupils to gauge their views on the method used in teaching writing.

\section{Result and Discussion \\ Pre-Test and Post Test}

The data from this research showed that the implementation of the STAD method is able to improve the pupils' descriptive writing skills. This was proved by the higher mean score that the pupils got in their post-test compared to the mean score that they got in the pre-test. 


\begin{tabular}{|ll|l|l|l|l|}
\hline & & & & Std. Error \\
& Mean & N & Std. Deviation & Mean & \\
\hline Pair 1 & Pretest & 50.03 & 34 & 14.882 & 2.552 \\
& Posttest & 59.74 & 34 & 16.200 & 2.778 \\
\hline
\end{tabular}

Table 1 Paired Samples Statistics

Table 1 shows the result of the descriptive essay writing in both pre-test and post test. Pre-test was carried out before the STAD method in this research conducted in the class, while the post test was carried out after the STAD method conducted in the lesson. In the pre-test, the overall mean score was 50.03 (Mean=50.03, SD=14.882). This table showed that the mean score in the post test was higher that pre-test which is 59.74 (Mean=5974, SD=16.200).

Table 2 Paired Samples Test

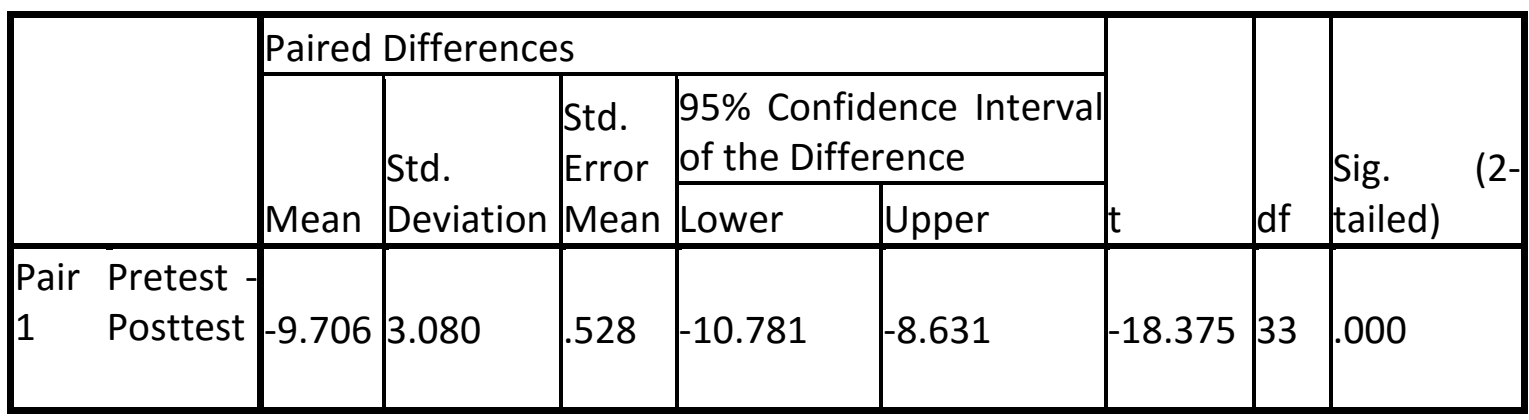

The differences of the means was 9.71 as shown in Table 2. The overall score were obtained based on how they write the descriptive essay which included the contents, style, organization of the essay and grammar used.

This result indicated that the overall score for post test was significantly higher that the pretest $(t=18.375, d f=22, p=.000)$. This concluded that the pupils get higher mark after the implementation of the STAD method in their lesson. They were able to answer the descriptive essay better when they cooperate with each other. STAD method allowed the pupils to learn and exchange their knowledge among themselves. The pupils also had the chance to ask questions and get easier explanation from their peers. This means that the STAD method was efficient to be conducted in the classroom in teaching descriptive essay writing. Therefore, this concluded that there are differences of mean score in the pre-test and post test after conducting the STAD method in classroom.

\section{Survey Questionnaires}

Table 3 is the descriptive statistics of the data collected from the survey questionnaire about the usage of STAD method in descriptive writing. 
INTERNATIONAL JOURNAL OF ACADEMIC RESEARCH IN BUSINESS AND SOCIAL SCIENCES Vol. 10, No. 2, Feb, 2020, E-ISSN: 2222-6990 @ 2020 HRMARS

\begin{tabular}{|c|c|c|c|c|c|c|}
\hline \multirow[t]{2}{*}{ Questions } & \multicolumn{5}{|c|}{ Participant's Responses } & \multirow{2}{*}{$\begin{array}{l}\text { Mean } \\
\text { Score }\end{array}$} \\
\hline & $\begin{array}{l}\text { Strongly } \\
\text { Disagree }\end{array}$ & $\begin{array}{l}\text { Disagre } \\
\text { e }\end{array}$ & Neutra & Agree & $\begin{array}{l}\text { Strongly } \\
\text { Agree }\end{array}$ & \\
\hline $\begin{array}{l}\text { 1. I like writing activities } \\
\text { before I learn using } \\
\text { STAD method. }\end{array}$ & $\begin{array}{l}0 \\
(0 \%)\end{array}$ & $\begin{array}{l}4 \\
(11.8 \%)\end{array}$ & $\begin{array}{l}18 \\
(52.9 \%\end{array}$ & $\begin{array}{l}12 \\
(35.3 \% \\
)\end{array}$ & $\begin{array}{l}0 \\
(0 \%)\end{array}$ & 3.24 \\
\hline $\begin{array}{l}\text { 2. I like to work with my } \\
\text { friends before I learn } \\
\text { using STAD method. }\end{array}$ & $\begin{array}{l}0 \\
(0 \%)\end{array}$ & $\begin{array}{l}0 \\
(0 \%)\end{array}$ & $\begin{array}{l}9 \\
(26.5 \% \\
)\end{array}$ & $\begin{array}{l}21 \\
(61.8 \% \\
)\end{array}$ & $\begin{array}{l}4 \\
(11.8 \%)\end{array}$ & 3.85 \\
\hline $\begin{array}{l}\text { 3. I think using STAD } \\
\text { method helps me to } \\
\text { write with more details. }\end{array}$ & $\begin{array}{l}0 \\
(0 \%)\end{array}$ & $\begin{array}{l}0 \\
(0 \%)\end{array}$ & $\begin{array}{l}0 \\
(0 \%)\end{array}$ & $\begin{array}{l}22 \\
(64.7 \% \\
)\end{array}$ & $\begin{array}{l}12 \\
(35.3 \%)\end{array}$ & 4.35 \\
\hline $\begin{array}{l}\text { 4. I think STAD method } \\
\text { helps to discuss with } \\
\text { friends about our } \\
\text { writing. }\end{array}$ & $\begin{array}{l}0 \\
(0 \%)\end{array}$ & $\begin{array}{l}0 \\
(0 \%)\end{array}$ & $\begin{array}{l}0 \\
(0 \%)\end{array}$ & $\begin{array}{l}9 \\
(26.5 \% \\
)\end{array}$ & $\begin{array}{l}25 \\
(73.5 \%)\end{array}$ & 4.74 \\
\hline $\begin{array}{l}\text { 5. I like writing activities } \\
\text { after I learn using STAD } \\
\text { method. }\end{array}$ & $\begin{array}{l}0 \\
(0 \%)\end{array}$ & $\begin{array}{l}0 \\
(0 \%)\end{array}$ & $\begin{array}{l}0 \\
(0 \%)\end{array}$ & $\begin{array}{l}13 \\
(38.2 \% \\
)\end{array}$ & $\begin{array}{l}21 \\
(61.8 \%)\end{array}$ & 4.62 \\
\hline $\begin{array}{l}\text { 6. I like to work with my } \\
\text { friends after I learn } \\
\text { using STAD method. }\end{array}$ & $\begin{array}{l}0 \\
(0 \%)\end{array}$ & $\begin{array}{l}0 \\
(0 \%)\end{array}$ & $\begin{array}{l}0 \\
(0 \%)\end{array}$ & $\begin{array}{l}6 \\
(17.6 \% \\
)\end{array}$ & $\begin{array}{l}28 \\
(82.4 \%)\end{array}$ & 4.82 \\
\hline $\begin{array}{l}\text { 7. I had fun using STAD } \\
\text { method in my writing } \\
\text { because it is simple and } \\
\text { easy. }\end{array}$ & $\begin{array}{l}0 \\
(0 \%)\end{array}$ & $\begin{array}{l}0 \\
(0 \%)\end{array}$ & $\begin{array}{l}0 \\
(0 \%)\end{array}$ & $\begin{array}{l}3 \\
(8.8 . \%)\end{array}$ & $\begin{array}{l}31 \\
(91.2 \%)\end{array}$ & 4.91 \\
\hline
\end{tabular}


INTERNATIONAL JOURNAL OF ACADEMIC RESEARCH IN BUSINESS AND SOCIAL SCIENCES Vol. 10, No. 2, Feb, 2020, E-ISSN: 2222-6990 @ 2020 HRMARS

\begin{tabular}{|l|l|l|l|l|l|l|}
\hline $\begin{array}{l}\text { 8. I would like the } \\
\text { teacher to use STAD } \\
\text { method for my future } \\
\text { writing activities. }\end{array}$ & $\begin{array}{l}0 \\
(0 \%)\end{array}$ & $\begin{array}{l}0 \\
(0 \%)\end{array}$ & $\begin{array}{l}3 \\
(8.8 . \%)\end{array}$ & $\begin{array}{l}31 \\
(91.2 \%)\end{array}$ & 4.91 \\
\hline
\end{tabular}

Table 3 Data Collected from survey questionnaire $(n=34)$

As shown in Table 3, there are total of 8 questions that had been answered by the pupils. This survey questionnaire was using the linear scale of 1 to 5 for the answers. The linear scale indicators is shown below:

1 - Strongly Disagree

2- Disagree

3- Neutral

4- Agree

5- Strongly Disagree

These questions were based on theme where the researcher distributed them into three themes. The themes are participants' motivational level (Questions 1, 7 and 8), participants' collaboration with others (Questions $2,4,6$ ) and the pupils improvement in using STAD method in writing (Questions 3, 5).

For the first theme which was participants' motivational level in using STAD method in writing, 35.3\% of the participants agreed to "I like writing activities before I learn using STAD method" with the mean score of 3.24 which is moderate. Meanwhile, question "I had fun using STAD method in my writing because it is simple and easy." and "I would like the teacher to use STAD method for my future writing activities." both got $8.8 . \%$ of the participants agreed and $91.2 \%$ strongly agree. These two questions both had 4.91 mean score which is high. This showed that the motivational level of the pupils in using STAD method in their descriptive writing is very high.

Next, for the participants collaborative with the others, $61.8 \%$ of the participants agreed and $11.8 \%$ of the participants strongly agreed to the question "I like to work with my friends before I learn using STAD method." with a mean score of 3.85. For question "I think STAD method helps to discuss with friends about our writing." $26.5 \%$ of the participants agreed and $73.5 \%$ of the participants strongly agreed with a mean score of 4.74. another question "I like to work with my friends after I learn using STAD method." which $17.6 \%$ of the participants agreed and $82.4 \%$ of the participants strongly agreed with a mean score of 4.82 . All of these three questions indicated high percentage of collaboration among the participants as they like it better when they work in group.

For the theme of pupils improvement, there was $64.7 \%$ of the participants agreed and $35.3 \%$ of the participants strongly agreed to the question "I think using STAD method helps me to write with more details." with 4.35 mean score. For the question "I like writing activities after I learn using STAD method." $38.2 \%$ of the participants and $61.8 \%$ of the participants strongly agreed with a mean score of 4.62 . This theme was also shown that both of the mean score are high where all the pupils agreed with both statements about their improvement after using STAD method in their writing class. 


\section{Interview}

The result of the interview revealed that the pupils like to use STAD method in writing lesson. This is because they have the chance to ask questions and share ideas with their group members. As stated by Yusuf, Natsir \& Hanum (2015) who quote Borich (2007), STAD method is where the pupils of mixed ability work in group in completing their tasks. The pupils were divided by their performance level, achievement and others. As they complemented each other in group, they had the fun of learning.

P1: I like STAD method because I can write together with my group members. I can ask questions if I do not know how to do the writing.

P2: I love it! I can more ideas and add them in my writing when I'm in my group.

STAD method is where the pupils have to cooperate with each other during their group work. From the interview, the participants stated that they tend to help each other more during the process. The helps and cooperation among the group members motivated the pupils to write their essay.

P3: We motivate each other when we feel like we cannot write the essay.

P4: We help each other through discussion. I feel motivated when I see my group members are active giving their ideas and sharing about how to write the essay.

Besides, the interview showed that the participants get benefits from this method. They can write better and do not afraid to write their ideas. They learned that they can have different ideas from their friends. This makes the pupils to be critical thinkers and think outside the box instead of scared to pour out their ideas.

P5: Yes, I got benefits from this method. After using this method, I get more ideas to write.

P6: I got benefits from this method as now I can write without being scared of writing the essay wrongly. I learned that any ideas can be accepted as long as the answers related to the topic.

Furthermore, the participants admitted that they want their teacher to use STAD method in their future lesson. They like the idea of working together with their friends. Achmad and Yusuf (2014) mentioned that the participants may be less intimidating when they ask questions from the friends instead of he teacher. Those of who are nervous or lacking of confident when talking to their teacher can seek their group members when encounter problems. This method open a door for the participants to work among themselves.

P7 : I hope the teacher can use this method in the classroom for other lessons. As writing is quite difficult for me, I think this method help me especially when I discuss the ideas with my group members.

P8: I like this method because I can work with my group members instead of working alone. I can share my problems with my group members and they help me to solve them.

\section{Conclusion}

The results of this study showed that the STAD method enhanced pupils in writing descriptive essay. The positive findings in this study indicated that teachers can apply STAD method in their teaching. Teachers can shift from the conventional approach which focus on teachers to a student-centered approach which is more interactive and allow collaboration among pupils. The results from the pre-test and post test, survey questionnaire and semi-stuructured interview indicated that the pupils work better using STAD method. This study shows that the STAD Method 
is able to grasp pupils' interest to write and expand their ideas in writing. This cooperative learning approach helps the pupils to see how they can work together to achieve higher marks in their study. This study also contributes to the approach that is more interactive and fun learning in the classroom. Pupils attracted more toward the lesson when they can collaborate with their friends. As this research was carried out to learn about the effects of STAD method on description writing, hence, further research should be done in order to compare the result in other English skills like listening, speaking and reading.

\section{References}

Achmad, D., \& Yusuf, Y. Q. (2014). Observing Pair-Work Task in an English Speaking Class. International Journal of Instruction, 7(1).

Ahmad, R. M. R. (2015). The Effectiveness of the Student-Centered Learning (SCL) Approach in Developing Some Writing Skills in English for the Secondary Stage Students. Beni-Suef University, Faculty of Education Curriculum and Instruction Dept.

Aldana, A. (2005). The process of writing a text by using cooperative learning. Profile: Issues in Teachers' Professional Development, 6(1): 47-57.

Borich, G. D. (2007). Effective Teaching Methods: Research-Based Practice, (6th Ed.). Upper Saddle River, NJ: Pearson Merrill Prentice Hall.

Burns, A. (1999). Collaborative Action Research for English Language Teachers. Cambridge: Cambridge University Press.

Cardoso, A., Pereira, S., Silva, E., \& Sousa (2009). On The Development Of Textual Competence In Primary Education. L1 - Educational Studies in Language and Literature, 9(4), 63-86.

Chitravelu, N., Sithamparan, S., Teh, S. C. (2005). ELT methodology : Principles and practice (2nd ed.). Selangor: Oxford Fajar Sdn. Bhd.

Cornelius, W., Jeffry, H., \& Adam, P. H. (2010). Learner-centered Instruction: Building Relationship for Student Success. N.P. Sage Publication.

Gustiana, Poetra \& Santoso. (2019). Improving The Students' Writing Narrative Text By Applying Cooperative Learning Type Student Teams Achievement Divisions (STAD). Professional Journal of English Education, Volume 2, No 4.

Hayashi, C. (2005). Scaffolding the academic writing process: A focus on developing ideas. Paper Presented at Lifelong Learning: Proceedings of the 4th Annual JALT Pan -SIG Conference. Tokyo, Japan: Tokyo Keizai University.

Ishtiaq, M., Ali, Z. and Salem, M. (2017). An experimental study of the effect of student teams achievement divisions (STAD) on vocabulary learning of EFL adult learners. Arab World English Journal, 8(3): 356-375.

Jacobs, G. (2006). Cooperative Learning and Second Language Teaching. Cambridge University Press.

Jones, L. (2007). The Student-centered Classroom. Cambridge University Press, 32 Avenue of the Americas, New York.

Kessler, G., Bikowski, D., and Boggs, J. (2012). Collaborative writing among second language learners in academic web-based projects. Language Learning \& Technology, 16(1): 91-101.

Kemmis, S., and McTaggart, R. (1988). The Action Research Planner (3rd Ed.), Geelong Deakin 
INTERNATIONAL JOURNAL OF ACADEMIC RESEARCH IN BUSINESS AND SOCIAL SCIENCES

Vol. 10, No. 2, Feb, 2020, E-ISSN: 2222-6990 ¿ 2020 HRMARS

University Press.

Koster, M., Tribushinina, E., De Jong, P. F., \& Van Den Bergh, H. (2015). Teaching children to write: A meta-analysis of writing intervention research. Journal of Writing Research, 7(2).

Mccombs, B., \& Whistler, J. (1997). The Learner-Centered Classroom and School for Increasing Student Motivation and Development. San Francisco: Jossey-Bass Publishers.

McMillan, K., \& Weyers, J. (2007). How to Write Essays \& Assignments. Pearson Education Limited, Edinburgh Gate, Harlow, Essex CM20 2JE, England.

Mahmoud, A., and Mohamed, M. (2014). The effectiveness of using the cooperative language learning approach to enhance EFL writing skills among Saudi university students. Journal of Language Teaching \& Research, 5(3): 616-625

Nair, S. M., and Kim, C. P. (2014). The effects of using the STAD method in teaching the short story, flipping fantastic on form one students. International Proceedings of Economics Development and Research, 81: 156.

Nunan, D. (1999). Second language teaching and learning. Australia: Heinle Cengag Learning.

Roybal, R. A. (2012). Creating Critical Thinking Writers in Middle School. A Look at the Jane

Schaffer Model. School of Education and Counseling Psychology Dominican Univ. of CaliforniaSan Rafael, CA. Retrieved May 2019 from http://eric.ed. gov/?q=SCL+ critical thinking

Samuel, R., and Bakar, Z. (2008). The effectiveness of 'VELT' in promoting English language communication skills: A case study in Malaysia. International Journal of Education and Development using Information and Communication Technology (IJEDICT). Vol. 4(3).

Slavin, R. E. (1994). A practical guide to cooperative learning. Boston: Allyn \& Bacon.

Wang, T. (2007). The Comparison of the Difficulties between Cooperative Learning and Traditional Teaching Methods in College English Teachers. The Journal of Human Resource and Adult Learning, 3(2): $23-30$.

Wyk, M. M. V. (2012). The effects of the STAD-cooperative learning method on student achievement, attitude and motivation in economics education. Journal of Social Sciences, 33(2): 261-270.

Yusuf, Y. Q., Natsir, Y., \& Hanum, L. (2015). A Teacher's Experience in Teaching with Student Teams-Achievement Division (STAD) Technique.International Journal of Instruction. Vol. 8(2).

Zarei, A. A., and Keshavarz, J. (2011). On the effects of two models of cooperative learning on EFL reading comprehension and vocabulary learning. Modern Journal of Language Teaching Methods. 